\title{
THE AESTHETIC REGIME OF POLITICS
}

\section{Introduction}

Although French philosopher Maurice Merleau-Ponty's early phenomenology of perception and his essays on art, politics, and language already showed an affinity between the aesthetic phenomena of expression and style, and the political and cultural dynamics of society at large, it was his late notion of flesh $^{1}$ that became crucial for grounding what I assume to be his aesthetico-political understanding of politics and ultimately democracy. The emergence of flesh as a concept was contemporary with Merleau-Ponty's break with Marxism as a philosophical model and with revolutionary dialectics as a political project. The move represented the earliest and more fundamental rejection of both the revolutionary "solution" to the indeterminate and conflictive character of social life and also to the technocratic and ideological attempt to eliminate democratic politics in the name of market efficiency and neoliberal radicalism - and his former student and friend Claude Lefort was the author who made the most out of this break. In theorizing the historical breakdown of the horizon of radical transcendence implied in the theologico-political regime and in denouncing the re-embracement of the One in the horizon of radical immanence in the totalitarian party's claim to having access to a complete knowledge of the social, Lefort developed a comprehensive understanding of the social in terms of flesh and of the political as its mise-en-forme, mise-en-sens, and mise-en-scène.

Due to lack of space, I will limit myself here to just outlining the major conclusions I extract from Merleau-Ponty's late philosophy ${ }^{2}$. His investigation moved from an early concern with the body as an incarnated and situated subject ${ }^{3}$ to a late concern with the general way of being he called flesh. Existing in the form of flesh was, for him, existing as simultaneously active and passive, subject and object, seer and visible. This way of transcending the idealist/materialist dichotomist approach that had dominated the history of modern Western thought was soon afterwards fully politicized by Lefort. For both authors, flesh thus became the way of being, not just of individual humans and animals, but also of society and the world at large. Moreover, the flesh of the social became, for Lefort much more explicitly than for Merleau-Ponty, a collective way of being of society that is neither just object nor just subject, neither just visible nor just seer, but both. This intertwining of activity and passivity of the social in which individuals, collective actors, and societies at large are all "reversible," "twodimensional" beings, at once active and passive, is, however, unable ever to achieve full transparency for itself. If I touch my left hand with my right hand - as Merleau-Ponty used to say, following Husserl - and then I switch to touching my right hand with my left hand, I still can never achieve an instance in which my hands are, at the same time, touching and touched; a chiasm always remains between my left

\footnotetext{
${ }^{1}$ «The flesh is not matter [...] it is not a fact or a sum of facts "material" or "spiritual" [...] To designate it, we should need the old term "element", in the sense it was used to speak of water, air, earth, and fire, that is, in the sense of a general thing, midway between the spatio-temporal individual and the idea, a sort of incarnate principle that brings a style of being wherever there is a fragment of being. The flesh is in this sense an "element" of Being»: M. Merleau-Ponty, The Visible and the Invisible, Evanston, Northwestern University Press, 1997, p. 139 (Le visible et l'invisible, Paris, Gallimard, 1979).

${ }^{2}$ For a longer version of this view, see M. Plot, Our Element. Flesh and Democracy in Merleau-Ponty, in «Continental Philosophy Review», 45, 2, pp. 235-59.

${ }^{3}$ M. Merleau-Ponty, Phenomenology of Perception, New York, Routledge, 2002 (Phénoménologie de la perception, Paris, Gallimard, 1945).
} 
hand as touched and my left hand as toucher, my right hand as touched and my right hand as toucher. Neither individuals nor societies can see-themselves-seeing; there is always a last-minute failure in the reversibility of flesh. Moreover, it is also the case that for all flesh there is always a "blind spot," since all seeing is always within the visible and thus unavoidably constitutes a region of invisibility for its vision - both of itself and of the world. This observation gives birth to a notion of "truth" in which, according to Merleau-Ponty, the introduction of two new concepts was required: hyperreflection and hyperdialectics - hyperreflection being a form of reason that takes its circumstance into account, not to achieve a complete picture of the whole but to recognize the impossibility of achieving such a thing; and hyperdialectics assuming, on the other hand, the same attitude regarding time: the whole is impossible to grasp; time's unfolding cannot be seen in simultaneity.

In my reading of Lefort's use of these findings, what takes place is a full assumption of the political implications behind the idea of the flesh of the social. In the same way as Merleau-Ponty's theory moved from the body to the flesh, Lefort's forms of society moved from the body (politic) to the flesh (of democracy). Flesh is an "element", as Merleau-Ponty said, in the sense the Greeks gave to the term. And no element can exist without a form. Nothing is merely flesh, in the same way as nothing is merely earth, water, air, or fire. Political forms in Lefort, forms of society, thus became styles of political configuration of the flesh of the social. In his work, the theologico-political form assumes that the political configuration of the flesh of the social springs from a transcendent, divine, and extrasocial source, and that its earthly representative is the figure of the single mon-arch. Inversely, for Lefort, the totalitarian form is the form that no longer conceives the political configuration of the social as transcendent. In the totalitarian form of society, the shaping of the social is radically immanent; it claims an internal point of view from which society becomes transparent for itself and can indeed seeitself-seeing - that is, a social actor claims for itself a point of view from which the social is visible completely and in simultaneity, from which society becomes fully reversible, fully able to see-itselfseeing. The form of society Lefort called modern democracy - and the regime I will soon suggest should, rather, be called "aesthetico-political" - assumes the "failure" in the last instance of the reversibility of the flesh of the social and institutes practices and institutions that are, in MerleauPonty's words, hyperreflective and hyperdialectic.

\section{A typology of regimes}

I will now move on to outline a relatively modified reading of Lefort's typology of theologicopolitical, modern-democratic, and totalitarian forms of society. This transformation/alteration will allow me to distance myself from the more conventional readings of the Lefortian model - probably even from his own reading of it - but I will do so in order to reclaim the validity of his democratic theory for the critical interpretation of our contemporary political life. The distance will not be too great, however. Following his notion of political regimes as forms of society, I will propose to see regimes as constellations of practices and institutions, social positions and interpretative horizons, successively inaugurated and made available, instituted, and sedimented. This is close to Lefort's view. In emphasizing the way in which regimes are capable of remaining in competing coexistence, however, I will try to render his typology more critically useful for our times.

In The Politics of Aesthetics ${ }^{4}$, French philosopher Jacques Rancière says the following:

\footnotetext{
${ }^{4}$ J. Rancière, The Politics of Aesthetics, New York, Continuum, 2006 (Le partage du sensible: Politique et esthétique, La Fabrique, Paris, 2000).
} 
I would say that my approach is a bit similar to Foucault's. It retains the principle from the Kantian transcendental that replaces the dogmatism of truth with the search of conditions of possibility. At the same time, these conditions are not conditions for thought in general, but rather conditions immanent in a particular system of thought, a particular system of expression. I differ from Foucault insofar as his archeology seems to me to follow a schema of historical necessity according to which, beyond a certain chasm, something is no longer thinkable, can no longer be formulated. The visibility of a form of expression as an artistic form depends on a historically constituted regime of perception and intelligibility. This does not mean that it becomes invisible with the emergence of a new regime [...]. Statements or forms of expression undoubtedly depend on historically constituted systems of possibilities that determine forms of visibility or criteria of evaluation, but this does not mean that we jump from one system to another in such a way that the possibility of the new system coincides with the impossibility of the former system, in this way, the aesthetic regime of art, for example, is a system of possibilities that is historically constituted but that does not abolish the representative regime, which was previously dominant. At a given point in time, several regimes coexist and intermingle in the works themselves ${ }^{5}$.

Lefort offered an interpretation, at once historical and philosophical, of the three forms of society he analyzed, all of them chronologically - but fundamentally genealogically - articulated out of Christological, European premodernity. This theologico-political form then mutated, significantly but not absolutely ${ }^{6}$ due to the modern dissolution of the markers of certainty, and finally witnessed the advent of the totalitarian rejection of such dissolution. The first limitation I want to attribute to this model relates to its theorization of these forms of society as seemingly mutually exclusive gestaltic quasi-totalities. In agreement with Rancière, I do not, of course, deny the existence of identifiable configurations or constellations of practices and institutions, articulations of dominant social relations and generative principles of collective life; configurations that, in fact, allow for certain practices to prevail over others, certain institutions over others, and so forth. Rather, I would like to suggest that the Lefortian regimes should be seen along the lines of the Rancièrian aesthetic regimes, that is, as sets of visibilities and invisibilities, of different generative principles superimposed and competing with each other at any given historical time. The Lefortian gesture - similarly to the Foucaultian one ${ }^{7}-$ turns the $^{-}$ appearance of new dispositifs and discursive formations into the institution of some sort of episteme; into a symbolic rupture, as Lefort would put it; into the inauguration of a form of society that would render obsolete the previously dominant dispositifs and discursive formations. At the same time, his model implied that the newly instituted articulations and regularities would seem to occupy the totality of the thinkable and to a large extent completely determine the universe of the unthinkable; to absolutely affirm the realm of the possible and to successfully monopolize the delineation of the impossible. The gesture is (for Lefort) strangely un-phenomenological and structural, and, thus, relatively unable to capture the dynamic of sedimentation and reactivation that keeps the past in the present and associates the future with the pregnancy of the past. In effect, the Lefortian gesture identifies with precision the appearance of new practices and vocabularies, new institutions and regularities; it captures, we can say, the emergence of a new social and political grammar. Sadly, what the gesture also does is engage in a sort of voluntary ignorance of the survival of vocabularies and practices previously instituted, of grammars that remain in tension with, and lying in wait for, the one

\footnotetext{
${ }^{5}$ Ivi, p. 50.

${ }^{6}$ C. Lefort, Permanence of the Theologico-Political?, in «Democracy and Political Theory», 1988.

${ }^{7}$ Carl Schmitt also established a certain correlation between the metaphysical discourse of an epoch and its political organization. His position, however, is very different from the historical relativism of Foucaultian epistemes. For Schmitt, in the end, there is only one acceptable metaphysical discourse - Catholicism - and therefore only one acceptable form of political organization - a theologico-political one. See C. Schmitt, Political Theology II. The Myth of the Closure of Any Political Theology, Malden, Polity Press, 2008 (Politische Theologie II. Die Legende von der Erledigung jeder politischen Theologie, Leipzig 1979).
} 
that has recently emerged. What I thus claim, in short, is that the Lefortian model, in its conventional reading, does not clearly capture the survival of the old in the new, the coexistence of competing political regimes within the context of the dominance of a given one.

The second suggestion I want to make is to modify, or, if I am allowed to use this unusual expression, "coherently deform", the Lefortian model once again, this time by establishing an analogy with the inspiration behind the Weberian ideal types. This move turns Lefortian forms of society into ideal types, not of legitimate forms of domination, but of horizons for the configuration of collective life instead. Weber never suggested that the dominant political legitimacy in a given society would be entirely and exclusively traditional, legal, or charismatic. Actually, every society presents an intertwining of those forms of legitimacy that does not exclude the possibility of identifying different hegemonies, distinctive decisive roles played by certain types of legitimate domination in a given society or during a certain historical period. This (hopefully) coherently deformed Lefortian model thus offers us a typology of coexisting and competing horizons for the configuration of collective life - of regimes of visibility and invisibility, of the thinkable and the unthinkable - that is also tripartite: (1) theologico-political, (2) aesthetico-political, and (3) epistemologico-political ${ }^{9}$.

The Rancièrian understanding of regimes I propose is based on establishing a temporal parallelism between his ethic regime of images and his representative regime of the arts and the theologicopolitical regime ${ }^{10}$. In this way, the aesthetic regime of art and the aesthetico-political regime (or simply the aesthetic regime of politics) appear with the modern emergence of the generative principle of equality, but do not for that reason make disappear - although they do profoundly put into question the theologico-political regime on the one hand, and the ethic regime of images and the representative regime of the arts on the other. Already in the context of the transformations introduced by the appearance of the aesthetic regime of politics, something similar occurred with the emergence of what Arendt, Lefort, and others have called "totalitarianism," but that I propose to transform into the most radical version, the one closest to the ideal type, of what I suggest should, rather, be described as epistemologico-political regimes.

Let me give two very brief examples of the kind of dynamic I have in mind. The alliance between Catholicism and the democratic opposition against the communist regimes of Central and Eastern Europe in the 1980s described by Lefort, for instance, should be interpreted, according to this understanding of political regimes, as an antiepistemologico-political alliance - antiepistemologicopolitical because they opposed the Communist Party's claim to being the practical embodiment of historical knowledge and necessity. Similarly, the alliance of political Christianity and the political epistemologies of the minimal state and free-market economy in the Republican Party of today's America - as much as that same alliance in the Latin American Southern Cone dictatorships of the 1970s and 1980s - should be interpreted as theologico-political and epistemologico-political alliances against the aesthetico-political regime, that is, against the egalitarian dissolution of the markers of certainty introduced by modern democracy and the political staging of social conflict and plurality it implies. To put it briefly: ontologically, political theologies and political epistemologies oppose each other in that they make incompatible otherworldly or scientific/philosophical claims to the monopoly of the determination of the thinkable and the unthinkable, the visible and the invisible. In practice,

\footnotetext{
${ }^{8}$ Merleau-Ponty's words for understanding a successful expression. See M. Merleau-Ponty, Indirect Language and the Voices of Silence, in Signs, Evanston, Northwestern University Press, 1998 (Signes, Paris, Gallimard, 1960).

${ }^{9} \mathrm{I}$ am afraid that this new terminology will facilitate the job of the theological and epistemological enemies of democracy, since it will always be easier to reject the already-demonized "aesthetic" principle than the name of democracy. I will see what can be done in that regard....

${ }^{10}$ J. Rancière, Aesthetics and Its Discontents, New York, Polity, 2010 and Id., The Politics of Aesthetics.
} 
however, they share their antiaesthetic character, since they are both antipluralist and antihyperdialectic.

\section{Political theology, political epistemology}

German political theorist and legal scholar Carl Schmitt was, of course, the main exponent and defender of the permanence of the theologico-political regime in times of aesthetico-political hegemony. For him, the idea was quite simple: One God - One King. Or, in his words of Political Theology II paraphrasing Eusebius: «[O]nly the victory of Christendom completes the victory of unity over plurality, the victory of the one true belief in God over the polytheism and the superstition of the polis of pagan peoples. The Roman Empire is the peace, the victory of order over uproar and over the factions of civil war: One God - One World - One Empire» ${ }^{11}$. When, in Political Theology, Schmitt states that «all significant concepts of the modern theory of the state are secularized theological concepts», he is partially right, though. The missed, however, is more important than the captured. The problem resides in the totalizing aspiration. Not all significant modern political concepts are secularized theological concepts, not even those circumscribed to a «modern theory of the state». Only those concepts that remain part of the theological regime of politics belong to Schmitt's secularized theological concepts in the modern vocabulary. It is correct to say that the theological regime of politics, the theologico-political form, remains available as a horizon for the organization of collective life even in modern times. The problem is that, in the context of modern democracy, it has not been the dominant regime as frequently as it was during European premodernity. When Schmitt thus offers his definition of the survival of political theology in all significant modern political concepts, he is, and is not, right for very specific reasons. He is right because no social and political change takes place ex nihilo, because all appearance of the new is, at the same time, a reconfiguration of elements of the past and, in this way, a perpetuation of some dimensions of those very elements. He is wrong, on the other hand, because in making such a claim Schmitt hopes to be dissipating the illusion that would, ludicrously, expect that some elements of modern politics could possibly have parted company with the theologico-political regime, since they would claim to have opened horizons for the organization of collective life in which concepts such as absolute decision, sovereignty as indivisible unity, existential enmity, and so on would no longer carry the implications that a political theology would demand from them. An immediate indication that Schmitt's fight against democratic "charlatans" might not be as winnable as he thought, however, was already present in the often redundant character of modern theologico-political concepts: why is there a need to add "absolute" to "decision," "indivisibility" to "sovereignty," and "existential" to "enmity"? The reason is simply that decision, sovereignty, and enmity no longer hold the antiplural, theologico-political connotations that Schmitt's understanding of them requires, since they no longer imply the weight that the theologico-political dispositif had successfully demanded from them in more triumphal times.

Schmitt's claim to be dissipating an illusion is, in fact, illusory itself, since it is an attempt to denounce as illegitimate and false the very appearance of new forms of conceiving legitimacy and truth. It is - we could almost say, following Arendt's critique of the Platonic understanding of the twoworld theory $^{12}$ - a fallacy, since it emerges from the hypostatization of one of the elements of the advent of the new (its not being ex nihilo), turning it into a totality (nothing new has happened). This is the reason why Schmitt is not only an extremely lucid exponent of the conservative perspective before

${ }^{11}$ C. Schmitt, Political Theology II, p. 91.

${ }^{12}$ H. Arendt, The Life of the Mind, New York, Harcourt Brace, 1978, pp. 23-30. 
the Lefortian dissolution of the markers of certainty but also the almost definitive theorist of modern revolution and modern dictatorship ${ }^{13}$. Schmitt, with his two-fold dictatorship - commissarial and sovereign - fully understood the novel political forms with which the theologico-political regime had to respond to the aesthetico-political modern uncertainty in times of crisis. As we know, however, since crisis situations can be neither truly anticipated in legislation nor objectively determined by science, the theologico-political dictatorship requires the mystification of one of the multiple possible (aesthetic) judgments on the situation, in this (mystical) way rendering this judgment theologically - or, in modern times, also epistemologically - sovereign. This mystification, which quite a few authors on today's theoretical left ask us to accept as unavoidable, is actually a tranquilizing gesture, since it simplifies the indeterminate spaces and times opened up by the equality of intelligences, as Rancière says ${ }^{14}$, the spaces and times in which anybody, and from any perspective, could claim the capacity to act and judge in collective life.

With those forms of - aesthetic and epistemological - critique of the theological monopoly on political authority and the validity of social norms first appearing with the Enlightenment, and then becoming decidedly political with the democratic revolutions of the late 18th and early 19th century, together with the persistent erosion of all forms of naturalization of hierarchical orders by the generative principle of equality, an alternative regime of politics emerged. It is this regime that I propose to call "aesthetico-political". The Tocquevillean/Lefortian generative principle of equality is, quite simply, the aesthetic principle: paraphrasing Rancière, the principle that anyone and everyone, whoever wants to, from whatever point of view, can judge and act in aesthetics and politics ${ }^{15}$. Inversely, the generative principle of hierarchy is, quite simply, the theological - and epistemological principle: not anyone and everyone, not merely whoever wants to, much less from any point of view, can judge and act. Here Lefort's theorizing once again re-emerges, since the stability claimed by theologico-political orders was due to the fact that the point of view from which it was possible and necessary to judge and act, that place that was not anywhere, was a transcendent one - and that, for Lefort, became radically immanent in the totalitarian form of society. The figure of the two bodies of the king gave this transcendent place an immanent locus - a necessary condition for the actual exercise of power - but did not stop for that reason to invoke a point of view on the social that in principle was not accessible to anyone because it did not belong to society; it transcended it and was anchored in an otherworldly beyond. It is for this reason that, in the modern context of the decapitation of the king and, thus, of the body politic, emptying in this way the place of power, as Lefort described, the accusation of destabilization that Schmitt and Koselleck made against the practice of - aestheticopolitical - critique $^{16}$ should actually be reversed. This can already be inferred, but it must still be fleshed out, from the Lefortian (and, surprisingly on this point, also Arendtian) view of the working of modern societies. For both Arendt and Lefort, totalitarian regimes were potentially vulnerable and weak. So, when Schmitt tells us that all significant modern political concepts are secularized theological concepts, what he is thus recognizing is that all modern theologico-political concepts become, after the successful challenge posed by the aesthetic regime of politics, suddenly deprived of a

\footnotetext{
${ }^{13}$ A. Arato, Conceptual History of Dictatorship (And Its Rivals), in Enrique Peruzzotti - Martin Plot (eds.), Critical Theory and Democracy, New York, Routledge, 2013.

${ }^{14}$ J. Rancière, Disagreement: Politics and Philosophy, Minneapolis, The University of Minnesota Press, 1999 , p. 34.

15 This is the central articulation between the Rancièrian contribution to democratic theory and the Lefortian reconstruction of the Tocquevillian narrative of the all-disrupting advent of modernity.

${ }^{16}$ R. Koselleck, Critique and Crisis. Enlightenment and the Pathogenesis of Modern Society, Cambridge, The MIT Press, 1988 (Kritik und Krise. Eine Studie über Pathogenese der bürgerlichen Welt, Frankfurt a.M., Suhrkamp, 1973; C. Schmitt, Crisis in Parliamentary Democracy, Cambridge, The MIT Press, 1988 (Die geistesgeschichtliche Lage des heutigen Parlamentarismus, Leipzig 1923).
} 
transcendent source of legitimacy. As a result of the appearance and frequent modern supremacy of the aesthetico-political horizon for the organization of collective life, it is the theologico-political form of the exercise of power that becomes unstable. In the words of Arendt and Lefort, what they called totalitarian - and I propose to rename epistemologico-political - regimes are inherently unstable because they are inflexible (Lefort) and inherently weak because they do not generate power (Arendt).

To put together both arguments, totalitarian regimes become incapable of adapting to new circumstances, to changes - in aesthetic perspectives, in the indeterminate character of the reconfigurations of the visible and the invisible characteristic of modern plurality - because they do not allow the exercise of, and the struggle for, democratic judgment and power. This is what turns decision and legitimacy into Schmitt's central concerns. The difficulty of legitimating the theologico-political decision is a destabilizing factor for any order aiming to fixate - that is, deaestheticize - the capacities to judge and act; in short, the decisionist view of the exercise of power. This turns Schmitt into not only the most articulate theologico-political contemporary thinker but also, as his own biography indicates, the precursor of the theorization of the epistemologico-political regime - that is, an advocate for the reestablishment of ultimate, absolute, irrevocable criteria and sources of authority, a theorist of sovereignty understood as the supreme and originary power to rule ${ }^{17}$; in short, a thinker of the sovereign and antipluralist decision, either theologically or epistemologically rooted.

It will be said that Schmitt was nonetheless a democratic thinker, that his dictatorship was a democratic dictatorship. The answer is that this was unavoidable to him, since his interlocutor in modern times was the aesthetico-political principle - in his Political Theology he says: «the form of aesthetic production [...] knows no decision» ${ }^{18}$ and this, of course, exasperates him. But this interlocution, this modern imperative of being democratic, made him become the theorist of the popular will as sovereign will, of the ideal of popular sovereignty not as an ever-changing horizon, as in Lefort, but as a source of theologico-political certainty, in act or by default - preferably by default, since there is no more "democratic," sovereign theologico-political decision than the one made by the leader and "silently" acclaimed by the people. Earlier I used the neologism "deaestheticizing" precisely because the theologico-political difficulty in times of aesthetico-political hegemony resides in its need to unravel the web of relationships knitted by the generative principle of equality - that is, by the democratic principle that is the aesthetic principle. It is the need to undo these decentralized webs of relationships, in which anyone and everyone can judge and aspire to exercise power, in order to redo them as those in which the capacity to judge and the exercise of power are again monopolized by a given perspective on the social, that turns modern political theologies into usually violent, quasirevolutionary and, once victorious, unstable phenomena ${ }^{19}$.

Again, this is why Schmitt is the theorist of both the commissarial (conservative) and the sovereign (revolutionary) types of modern dictatorship. A sovereign dictatorship, for Schmitt, operates in a legal void that is mythically seen as democratically full, as a moment of unlimited - due to its legal vacuum - but legitimate exercise of power ${ }^{20}$. The model is a dichotomist one, a model of pouvoir constitué and

${ }^{17}$ C. Schmitt, Political Theology, Chicago, The University of Chicago Press, 2006 (Politische Theologie. Vier Kapitel zur Lehre von der Souveränität, Leitpzig 1922).

${ }^{18}$ Ivi, p. 35.

${ }^{19}$ In Roman Catholicism and Political Form, Schmitt presents the modern state as having distanced itself - aestheticopolitically, I would say - from his model of theologico-political authority. This view brings him closer to the position I outline in this paper, only in a pessimist, melancholy way. See C. Schmitt, Roman Catholicism and Political Form, Praeger 1996 (Römischer Katholizismus und politische Form, 1923).

${ }^{20}$ See A. Arato, Civil Society, Constitution, and Legitimacy, Lanham, Rowman \& Littlefield, 2000; Id., Constitution Making Under Occupation, New York, Columbia University Press, 2009; and Id., Conceptual History of Dictatorship (and its Rivals), in Enrique Peruzzotti - Martin Plot (eds.) Critical Theory and Democracy. 
pouvoir constituant, since it cannot conceive of an order not based on a constituent - transcendent or immanent, theological or epistemological - source of political authority. Schmitt is a conservative and a revolutionary thinker at the same time. Modern democracy in Lefort's words, the aesthetico-political regime in my conceptualization, is the hyperreflexive and hyperdialectic alternative to this dichotomist view. The Schmittian dictatorship is the affirmation, either protective or constituent, of normality. Inversely, collective life under the influence of the generative principle of equality is never either fully constituted or in need of the radicalism of the constituent; it should, instead, be thought along the lines of the notion of "institution",21, that is, of the self-instituting dynamic, neither exterior to itself nor capable of seeing the whole, of the flesh of the social.

Let me conclude the text with a more precise justification for the choice of the notion of the epistemologico-political as a critically reactivated substitute for that of totalitarianism - and here I will develop the argument with Arendt and Lefort, rather than against Schmitt. What fundamentally motivates the need to revisit the concept of totalitarianism is that the concept has presented many more problems than solutions in our goal to understand contemporary politics and political regimes ${ }^{22}$. On the one hand, in some circles, the concept continues to be too closely associated with its use during the Cold War, when it was little more than a grotesque tool in the global cultural war against the Soviet Union - and, soon afterwards, against political Islam. On the other hand, even when successfully disentangled from such connotations, as is often the case in the context of debates within the tradition of continental social and political thought, the concept of totalitarianism remains too closely associated with the memory of the extermination and labor camps, with the holocaust and total domination, to be critically reactivated before contemporary events and transformations. Understandably, the concept established a threshold too difficult - although, sadly, not impossible - to reach.

Totalitarianism, however, when it was first developed as a concept and used analytically by its two main theorists Arendt and Lefort, signaled in a direction that can and must be freed from such connotations. The direction in which the concept signaled is easy to reconstruct: totalitarian domination, in both its Nazi and Bolshevik incarnations, was a domination based, according to Arendt, in the claim to a total knowledge of history and nature ${ }^{23}$, and, in Lefort, this domination materialized itself in the fusion of the spheres of power, knowledge, and right, and its subsequent reincorporation of power into an organ, the totalitarian party ${ }^{24}$. This is, in brief, precisely the reason why I propose to give the name of epistemologico-political to the type of regime that builds on the legacy of totalitarianism. This regime, however, should be understood in the way here suggested, that is, as a horizon for the configuration of collective life. Understood in this way, the practices, institutions, standards, and criteria for the distribution of the acceptable and the unacceptable, the visible and the invisible, that belong to this regime of the partition of the perceptible - to use Rancière's expression - are not completely disarticulated and disabled in its times of weakness. On the contrary, these alternative regimes remain latent, or even in open competition with the other regimes.

\footnotetext{
21 See M. Merleau-Ponty, Institution and Passivity, Evanston, Northwestern University Press, 2010 (L'institution/La passivité. Notes de cours au Collège de France (1954-1955)), Paris, Éditions Belin, 2003.

${ }^{22}$ A. Arato, Dictatorship Before and After Totalitarianism, in «Social Research», 69, 2, pp. 473-503.

${ }^{23}$ H. Arendt, Ideology and Terror, in The Origins of Totalitarianism, Cleveland, Meridian, $1963\left(1951^{1}\right)$.

${ }^{24}$ C. Lefort, The Political Forms of Modern Society.
} 